\title{
ДИНАМІКА ПОКАЗНИКІВ ЦИТОЛІЗУ ЗА УМОВ ГОСТРОЇ КРОВОВТРАТИ, УСКЛАДНЕНОЇ ІШЕМІЄЮ-РЕПЕРФУЗІЄЮ КІНЦІВКИ, ТА ЇХ КОРЕКЦІЯ КАРБАЦЕТАМОМ
}

Вступ. Основним засобом порятунку поранених на полі бою за умов масивної крововтрати з кінцівок $\epsilon$ застосування кровоспинного джгута. Відомо, що повне знекровлення кінцівки протягом 2 год у реперфуузійний період супроводжується активацією процесів ліпідної пероксидації, яка посилюється при гострій крововтраті, супроводжується деградацією клітинних мембран і зумовлює розвиток синдрому цитолізу.

Мета дослідження - з'ясувати динаміку показників цитолізу за умов гострої крововтрати, ускладненої ішемією-реперфузією кінцівки, та ефективність їх корекції карбацетамом.

Методи дослідження. В експериментах на нелінійних білих щурах-самцях під тіопентал-натрієвим наркозом моделювали двогодинну ішемію кінцівки з наступною реперфузією, гостру крововтрату (20\% від об'єму циркулюючої крові) та поєднували ці ушкодження. В окремій дослідній групі за умов гострої крововтрати та ішемії-реперфузії кінцівки щурам з корегувальною метою внутрішньочеревно вводили карбацетам у дозі 5 мг/кг маси тварини. У контрольній групі щурів вводили в наркоз. Через 1 і 2 год, а також через 1, 7 та 14 діб під тіопентал-натрієвим наркозом піддослідних тварин виводили з експерименту методом тотального кровопускання із серця. У сироватці крові визначали вміст маркерів цитолізу: активність аланін- і аспартатамінотрансфераз (АлАТ, АсАT).

Результати й обговорення. Моделювання ішемії-реперфузії кінцівки супроводжувалось вираженим цитолітичним синдромом, що, порівняно з контролем, проявлялось істотним зростанням активності в сироватці крові АлАТ і АсАТ через 3 год й 1 добу спостереження. Починаючи із 7-ї доби, показники нормалізувались. Моделювання гострої крововтрати поглиблювало активність процесів цитолізу. Досліджувані показники були більшими від рівня контролю в усі терміни спостереження з максимумом через 1 добу експерименту і суттєво перевищували показники дослідної групи, в якій моделювали лише ішемію-реперфрузію кінцівки. За умов гострої крововтрати, ускладненої ішемією-реперфузією кінцівки, порушення були більш значними. Досліджувані показники суттєво переважали в усі терміни спостереження контрольну та інші дослідні групи: активність АлАT - через 1-14 діб спостереження, АсAT - через 2 год - 7 діб. Застосування з метою корекції карбацетаму в щурів із гострою крововтратою, ускладненою ішемією-реперфузією кінцівки, показало, що через 7-14 діб його використання активність АлАТ і АсАТ у сироватці крові, порівняно з тваринами без корекції, істотно знижувалася, проте не досягала рівня контролю.

Висновок. Отримані результати свідчать про вагому роль прочесів цитолізу в патогенезі гострої крововтрати, ускладненої ішемією-реперфузією кінцівки, а також про перспективність використання карбацетаму як комплексного засобу для зменшення проявів ішемії-реперфузії кінцівки за умов гострої крововтрати. цетам.

КЛЮчОВІ СЛОВА: гостра крововтрата; ішемія-реперфузія кінцівки; цитолітичний синдром; карба-

ВСТУП. Гостра масивна крововтрата з кінцівок належить до головних причин смерті за умов бойової травми [1]. Застосування при цьому кровоспинного джгута є основним заходом порятунку поранених на полі бою. Відповідно до існуючих настанов, граничний термін накладання джгута становить 2 год.

Як показано в ряді експериментальних досліджень, повне знекровлення кінцівки протягом 2 год у реперфузійний період супроводжується посиленням процесів ліпідної пероксидації у внутрішніх органах, яке навіть на тлі компенса(c) І. І. Горбань, А. А. Гудима, Р. В. Максимів, 2020. торного зростання активності каталази не знижується протягом 14-ти діб експерименту [2, 3]. Враховуючи те, що в реальних умовах накладання джгута, як правило, супроводжується крововтратою, було проведено експерименти, під час яких поєднували гостру крововтрату 3 ішемією-реперфузією кінцівки. Автори переконливо довели, що при гострій крововтраті додаткове моделювання ішемії-реперфузії кінцівки здатне поглиблювати порушення процесів пероксидного окиснення ліпідів (ПОЛ) [4]. Аналогічно значно зростає інтенсивність ПОЛ внаслідок додаткового моделювання ішемії-реперфузії 
кінцівки за умов поєднаної травми живота $[5,6]$.

Відомо, що наслідками переокиснення ліпідів і протеїнів клітинних мембран на початковому етапі є збільшення їх проникності, порушення функції та ініціація подальшої загибелі клітин шляхом некрозу чи апоптозу [7]. Деградація клітинних мембран сприяє виходу цитоплазматичних ензимів у міжклітинний простір, а далі-у кров, що посилює ендотоксикоз і замикає чергове "хибне" патологічне коло, яке може призвести до розвитку синдрому системної відповіді організму на запалення $[8,9]$.

Проте недостатньо вивченим залишається питання щодо формування цитолітичного синдрому при гострій крововтраті, поєднаній із двогодинною ішемією кінцівки. Немає даних стосовно ефективності за цих умов карбацетаму, одним з механізмів дії якого є мембраностабілізувальний вплив [10].

Мета дослідження - з'ясувати динаміку показників цитолізу за умов гострої крововтрати, ускладненої ішемією-реперфузією кінцівки, та ефрективність їх корекції карбацетамом.

МЕТОДИ ДОСЛІДЖЕННЯ. Експерименти виконано на 108-ми нелінійних білих щурах-самцях масою 200-220 г з дотриманням правил Європейської конвенції про захист хребетних тварин, що використовуються для дослідних та інших наукових цілей (Страсбург, 1986).

Усіх тварин поділили на 5 груп: контрольну і 4 дослідних (по 6 щурів у кожній). Усі втручання виконано під тіопентал-натрієвим наркозом. У 1-й дослідній групі тваринам моделювали ішемію-реперфузію кінцівки шляхом накладання проксимально на ліву лапку смужки еластичного джгута "SWAT-T" (США) шириною 10 мм на 120 хв. Джгут затягували відповідно до нанесеного на нього індикатора ефективного тиску, який припиняє кровотік. У 2-й дослідній групі моделювали гостру крововтрату (20 \% від об'єму циркулюючої крові) шляхом пересікання стегнової вени. У 3-й дослідній групі ці ушкодження поєднували. У 4-й дослідній групі щурам із гострою крововтратою та ішемією-реперфузією кінцівки з корегувальною метою внутрішньочеревно вводили карбацетам (Інститут фрізико-органічної хімії та вуглехімії НАН України, Донецьк) у дозі 5 мг/кг маси тварини [3]. У контрольній групі тварин вводили в наркоз, застосовуючи еквівалентну дозу тіопентал-натрію, накладали джгут на 2 год без припинення кровотоку і надалі брали для досліджень через 1 год.

Через 1 і 2 год, а також через 1, 7 та 14 діб під тіопентал-натрієвим наркозом піддослідних тварин виводили з експерименту методом тотального кровопускання із серця. Уніфікованим методом для аналізатора біохімічного "Humalyzer 2000" в сироватці крові визначали вміст маркерів цитолізу: активність ензимів аланін- і аспартатамінотрансорераз (АлАТ, АсАТ).

Вірогідність відмінностей між дослідними групами оцінювали з використанням непараметричного критерію Манна - Уїтні.

РЕЗУЛЬТАТИ Й ОБГОВОРЕННЯ. УНасЛіДОК моделювання ішемії-реперфузії кінцівки в сироватці крові зростала активність АлАТ (табл. 1). Порівняно 3 контролем результат виявився статистично значущим через 3 год й 1 добу експерименту (відповідно, на 39,5 і 18,3 \%, p<0,05). Надалі показник нормалізувався і ставав істотно меншим, ніж через 3 год й 1 добу експерименту $(p<0,05)$.

Після моделювання гострої крововтрати показник перевищував контроль у всі терміни спостереження. Максимум порушень наставав через 1 добу. В цей термін показник був більшим на 87,2 \% $(p<0,05)$ і статистично вірогідно перевищував попередні терміни спостереження $(p<0,05)$. До 14-ї доби він знижувався, проте навіть через 14 діб був більшим від контролю на $44,6 \%(p<0,05)$.

Після моделювання гострої крововтрати, ускладненої ішемією-реперфузією кінцівки, показник теж у всі терміни спостереження був статистично вірогідно більшим від контролю, досягаючи максимуму через 1 добу (у 2,21 раза, p<0,05). В цей термін він також виявився істотно вищим порівняно $з$ попередніми термінами спостереження $(p<0,05)$. До 14-ї доби показник знижувався, проте був на 67,3 \% більшим, ніж у контрольній групі.

Порівняння дослідних груп між собою показало, що внаслідок гострої крововтрати (2-га дослідна група) активність у сироватці крові АлАТ була істотно більшою порівняно з групою, в якій моделювали лише ішемію-реперсузію кінцівки (1-ша дослідна група), через 2 год, 1, 7 і 14 діб експерименту $\left(p_{1-2}<0,05\right)$. За умов гострої крововтрати, ускладненої ішемією-реперфузією кінцівки (3-тя дослідна група), показник виявився суттєво вищим, порівняно з 1-ю дослідною групою, у всі терміни спостереження $\left(\mathrm{p}_{1-3}<0,05\right)$, а порівняно з 2-ю дослідною групою - через 1, 7 і 14 діб $\left(p_{2-3}<0,05\right)$.

У свою чергу, активність АсАТ під впливом самої ішемії-реперфузії кінцівки теж зростала порівняно $з$ контролем (табл. 2). Результат виявився статистично вірогідним через 3 год й 1 добу спостереження (відповідно, на 15,8 і $13,5 \%, p<0,05)$. 
Таблиця 1 - Активність аланінамінотрансферази в сироватці крові (ОД· $\left.\boldsymbol{л}^{-1}\right)$ після гострої крововтрати, ускладненої ішемією-реперфузією кінцівки (Me (LQ; UQ)) - медіана (нижній і верхній квартилі)

\begin{tabular}{|c|c|c|c|c|c|}
\hline \multirow{2}{*}{ Дослідна група } & \multicolumn{5}{|c|}{ Термін реперфузійного періоду } \\
\hline & 2 год & З год & 1-ша доба & 7-ма доба & 14-та доба \\
\hline \multicolumn{6}{|c|}{ Контроль $=86,3(77,5 ; 87,9)(\mathrm{n}=6)$} \\
\hline $\begin{array}{l}\text { 1-ша } \\
\text { (ішемія-реперфуузія) }\end{array}$ & $\begin{array}{c}92,4 \\
(82,4 ; 99,5) \\
(n=6)\end{array}$ & $\begin{array}{c}120,4^{\star 2 r} \\
(105,6 ; 133,2) \\
(n=6)\end{array}$ & $\begin{array}{c}116,7^{* 2 \Gamma} \\
(106,7 ; 118,3) \\
(n=6)\end{array}$ & $\begin{array}{c}96,4^{3,1 \mathrm{~A}} \\
(84,0 ; 102,1) \\
(\mathrm{n}=6)\end{array}$ & $\begin{array}{c}88,6^{3 г, 1 д} \\
(82,2 ; 92,3) \\
(n=6)\end{array}$ \\
\hline $\begin{array}{l}\text { 2-га } \\
\text { (гостра крововтрата) }\end{array}$ & $\begin{array}{c}114,4^{*} \\
(100,6 ; 118,0) \\
(n=6)\end{array}$ & $\begin{array}{c}134,6^{\star 2 r} \\
(125,3 ; 138,5) \\
(n=6)\end{array}$ & $\begin{array}{c}161,6^{\star 2,3 r} \\
(150,8 ; 165,5) \\
(n=6)\end{array}$ & $\begin{array}{c}140,1^{* 2 \Gamma, 1 д} \\
(134,3 ; 143,3) \\
(n=6)\end{array}$ & $\begin{array}{c}124,8^{* 2 r, 1 д} \\
(117,4 ; 134,8) \\
(n=6)\end{array}$ \\
\hline $\begin{array}{l}\text { 3-тя } \\
\text { (ішемія-реперфрузія+ } \\
\text { гостра крововтрата) }\end{array}$ & $\begin{array}{c}116,5^{\star} \\
(103,1 ; 119,4) \\
(n=6)\end{array}$ & $\begin{array}{c}140,5^{\star 2 r} \\
(134,4 ; 160,0) \\
(n=6)\end{array}$ & $\begin{array}{c}191,3^{\star 2,3 г} \\
(172,4 ; 197,1) \\
(n=6)\end{array}$ & $\begin{array}{c}171,7^{\star 2 r, 3 r} \\
(155,4 ; 180,0) \\
(n=6)\end{array}$ & $\begin{array}{c}144,4^{\star 2,3 r, 1 д, 7 д} \\
(139,9 ; 152,2) \\
(n=6)\end{array}$ \\
\hline$p_{1-2}$ & $<0,05$ & $>0,05$ & $<0,05$ & $<0,05$ & $<0,05$ \\
\hline$p_{1-3}$ & $<0,05$ & $<0,05$ & $<0,05$ & $<0,05$ & $<0,05$ \\
\hline$p_{2-3}$ & $>0,05$ & $>0,05$ & $<0,05$ & $<0,05$ & $<0,05$ \\
\hline
\end{tabular}

Примітка. Тут і в таблиці 2:

1. * - відмінності стосовно контрольної групи статистично вірогідні $(p<0,05)$.

2. $\mathrm{p}_{1-2}$ - вірогідність відмінностей між 1-ю і 2-ю дослідними групами.

3. $\mathrm{p}_{1-3}$ - вірогідність відмінностей між 1-ю і 3-ю дослідними групами.

4. $\mathrm{p}_{2-3}$ - вірогідність відмінностей між 2-ю і 3-ю дослідними групами.

5. 2г,3r,1д,7д - відмінності стосовно 2 і 3 год, а також 1-ї та 7-ї діб експерименту статистично вірогідні (р<0,05).

Таблиця 2 - Активність аспартатамінотранссерази в сироватці крові (Од· $\left.\boldsymbol{л}^{-1}\right)$ після гострої крововтрати, ускладненої ішемією-реперфузією кінцівки (Me (LQ; UQ)) - медіана (нижній і верхній квартилі)

\begin{tabular}{|c|c|c|c|c|c|}
\hline \multirow{2}{*}{ Дослідна група } & \multicolumn{5}{|c|}{ Термін реперфузійного періоду } \\
\hline & 2 год & 3 год & 1-ша доба & 7-ма доба & 14-та доба \\
\hline \multicolumn{6}{|c|}{ Контроль $=114,9(107,1 ; 120,8)(\mathrm{n}=6)$} \\
\hline $\begin{array}{l}\text { 1-ша } \\
\text { (ішемія-реперфузія) }\end{array}$ & $\begin{array}{c}120,4 \\
(105,8 ; 128,8) \\
(n=6)\end{array}$ & $\begin{array}{c}133,1^{\star 2 r} \\
(130,1 ; 140,6) \\
(n=6)\end{array}$ & $\begin{array}{c}130,4^{\star} \\
(115,2 ; 139,4) \\
(n=6)\end{array}$ & $\begin{array}{c}125,1 \\
(117,3 ; 138,3) \\
(n=6)\end{array}$ & $\begin{array}{c}119,5^{3 r} \\
(118,8 ; 127,3) \\
(n=6)\end{array}$ \\
\hline $\begin{array}{l}\text { 2-га } \\
\text { (гостра крововтрата) }\end{array}$ & $\begin{array}{c}140,8^{\star} \\
(132,4 ; 145,6) \\
(n=6)\end{array}$ & $\begin{array}{c}166,7^{\star 2 \Gamma} \\
(163,5 ; 178,8) \\
(n=6)\end{array}$ & $\begin{array}{c}210,4^{\star 3 r} \\
(180,9 ; 222,5) \\
(n=6)\end{array}$ & $\begin{array}{c}160,9^{\star 2 r, 1 A} \\
(151,3 ; 171,0) \\
(n=6)\end{array}$ & $\begin{array}{c}147,2 * 3,1 \mathrm{~A} \\
(141,9 ; 155,7) \\
(\mathrm{n}=6)\end{array}$ \\
\hline $\begin{array}{l}\text { 3-тя } \\
\text { (ішемія-реперфуузія+ } \\
\text { гостра крововтрата }\end{array}$ & $\begin{array}{c}161,0^{\star} \\
(156,0 ; 167,7) \\
(n=6)\end{array}$ & $\begin{array}{c}196,1^{\star 2 \Gamma} \\
(185,8 ; 203,4) \\
(n=6)\end{array}$ & $\begin{array}{c}265,0 * 2 r, 3 r \\
(234,4 ; 276,4) \\
(n=6)\end{array}$ & $\begin{array}{c}201,3^{* 2,1,1 A} \\
(185,6 ; 213,8) \\
(n=6)\end{array}$ & $\begin{array}{c}160,4^{* 3,11,7 д} \\
(155,5 ; 167,2) \\
(n=6)\end{array}$ \\
\hline $\mathrm{p}_{1-2}$ & $<0,05$ & $<0,05$ & $<0,05$ & $<0,05$ & $<0,05$ \\
\hline$p_{1-3}$ & $<0,05$ & $<0,05$ & $<0,05$ & $<0,05$ & $<0,05$ \\
\hline $\mathrm{p}_{2-3}$ & $<0,05$ & $<0,05$ & $<0,05$ & $<0,05$ & $>0,05$ \\
\hline
\end{tabular}

Після моделювання гострої крововтрати порушення були більш вираженими. Показнику всі терміни спостереження виявився істотно вищим порівняно з контролем. Максимум порушень наставав через 1 добу (на 83,1\%, p<0,05) 3 наступним зниженням до 14-ї доби. У цей термін показник був на 28,1 \% більшим, ніж у контрольній групі $(p<0,05)$, і суттєво меншим порівняно 33 год та 1-ю добою спостереження $(p<0,05)$.

Одночасне моделювання гострої крововтрати й ішемії-реперфузії кінцівки зумовило більш виражене зростання активності АсАТ у сироватці крові. На максимумі порушень - через 1 добу показник перевищував контроль у 2,31 раза $(p<0,05)$. До 14-ї доби він знижувався, проте продовжував перевищувати контроль на 39,6 \% $(p<0,05)$. У цей термін показник ставав також істотно меншим порівняно 3 год, 1-ю і 7-ю добами спостереження $(p<0,05)$.

Порівняння дослідних груп між собою показало, що у 2-й дослідній групі на тлі гострої крововтрати активність АсАТ у сироватці крові в усі терміни спостереження статистично вірогідно була більшою від показника 1-ї дослідної групи, в якій моделювали лише ішемію-реперфузію кінцівки $\left(\mathrm{p}_{1-2}<0,05\right)$. Після моделювання гострої крововтрати, ускладненої ішемією-реперфузією кінцівки (3-тя дослідна група), вона в усі терміни спостереження перевищувала показник 1-ї до- 
слідної групи ( $\left.p_{1-3}<0,05\right)$, а через 2 і 3 год та 1 й 7 діб - 2-ї дослідної групи ( $\left.p_{2-3}<0,05\right)$.

Таким чином, моделювання ішемії-реперфузії кінцівки супроводжувалось вираженим цитолітичним синдромом, що, порівняно з контролем, проявлялось істотним зростанням активності в сироватці крові АлАТ і АсАТ через 3 год й 1 добу спостереження. Починаючи із 7-ї доби, показники нормалізувались. Моделювання гострої крововтрати поглиблювало активність процесів цитолізу. Досліджувані показники були більшими від рівня контролю в усі терміни спостереження 3 максимумом через 1 добу експерименту і суттєво перевищували показники 1-ї дослідної групи. За умов гострої крововтрати, ускладненої ішемією-реперфузією кінцівки, порушення були більш значними. Вони переважали в усі терміни спостереження контрольну та інші дослідні групи.

Як свідчать отримані результати, внаслідок моделювання гострої крововтрати, ускладненої ішемією-реперфузією кінцівки, в печінці піддослідних тварин поглиблювалась деградація клітинних мембран, що створювало передумови посилення їх проникності. У результаті в системний кровотік надходили цитоплазматичні ензими АлАТ і АсАТ.

Як показали наші попередні дослідження, посилення цитолітичного синдрому за амплітудою і термінами збігається з активацією в печінці процесів ліпідної пероксидації [11], що підтвер- джує існуючу гіпотезу про провідну роль ПОЛ у посиленні процесів цитолізу з накопиченням у крові їх маркерів. Ми вперше довели, що ускладнення гострої крововтрати ішемією-реперорузією кінцівки супроводжується статистично значущим посиленням цитолітичного синдрому, це, очевидно, пов'язано з нашаруванням патогенних механізмів як гострої крововтрати, так й ішемії-реперфузії кінцівки. Подібну закономірність відмічали й інші автори в реперфузійний період за умов поєднаної травми живота після додаткової двогодинної ішемії кінцівок [12].

Застосування з метою корекції карбацетаму показало (рис. 1, 2), що через 7 діб його використання активність АлАТ у сироватці крові, порівняно з тваринами без корекції, знижувалась на $17,3 \%$ (p<0,05), через 14 діб - на 10,3\% (p<0,05). Аналогічно під впливом карбацетаму зменшувалась активність й АсАТ у сироватці крові: через 7 діб - на 23,4 \% (p<0,05), через 14 діб - на 22,0 \% ( $<<0,05)$. Слід зауважити, що до 14-ї доби показники під впливом корекції не досягали рівня контролю $(p<0,05)$. Незважаючи на вищесказане, можна говорити про виражений мембранопротекторний вплив карбацетаму при гострій крововтраті, ускладненій ішемією-реперфузією кінцівки. Це вказує на вагому роль процесів цитолізу в патогенезі досліджуваної патології травми, а також на перспективність використання карбацетаму як комплексного засобу для

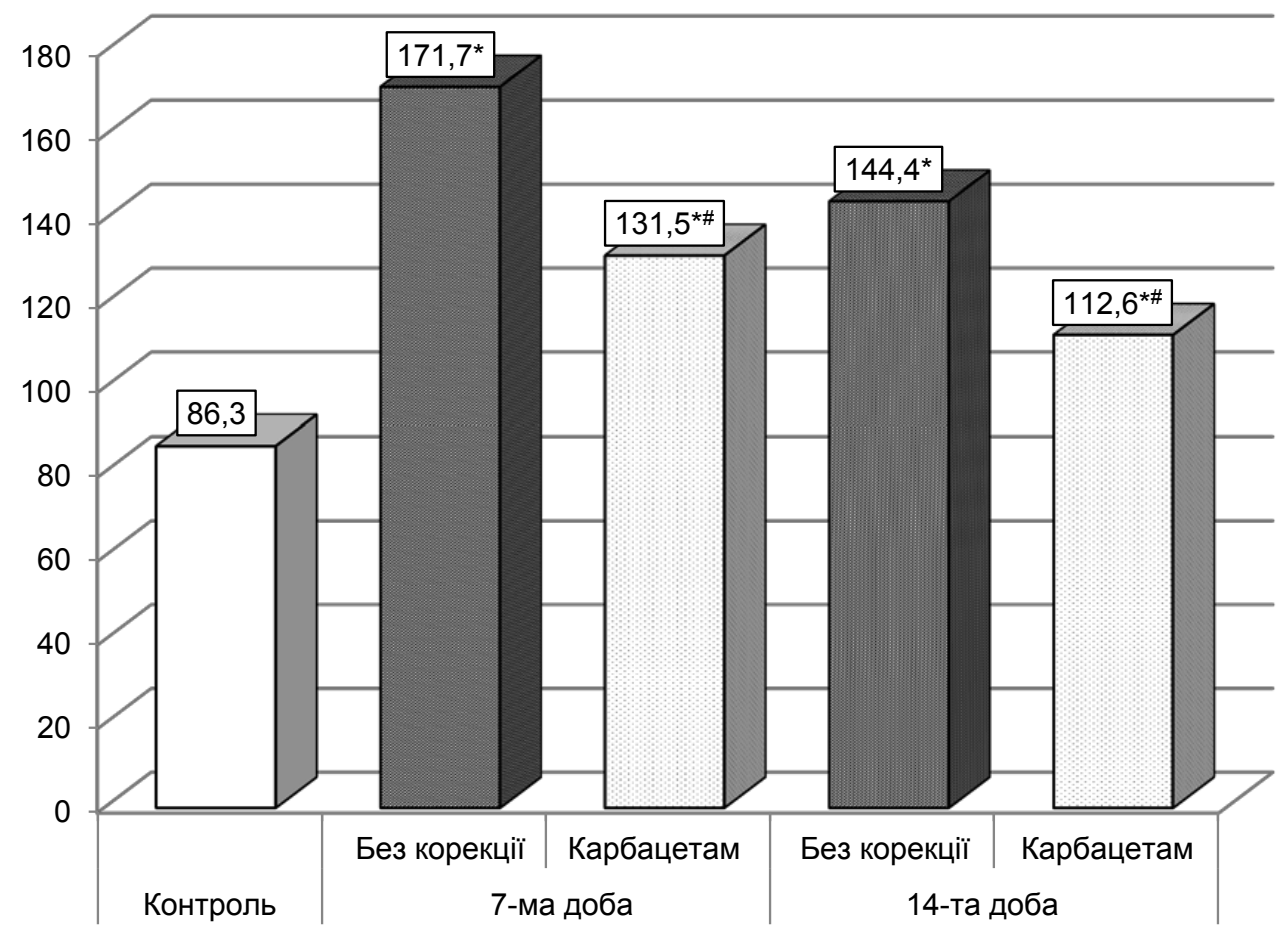

Рис. 1. Вплив карбацетаму на активність аланінамінотрансферази в сироватці крові (Од·л $\left.{ }^{-1}\right)$ після гострої крововтрати, ускладненої ішемією-реперфузією кінцівки.

Примітка. Тут і на рисунку 2: * - відмінності стосовно контролю статистично вірогідні $(p<0,05)$; ${ }^{*}$ відмінності стосовно групи без корекції статистично вірогідні $(p<0,05)$. 


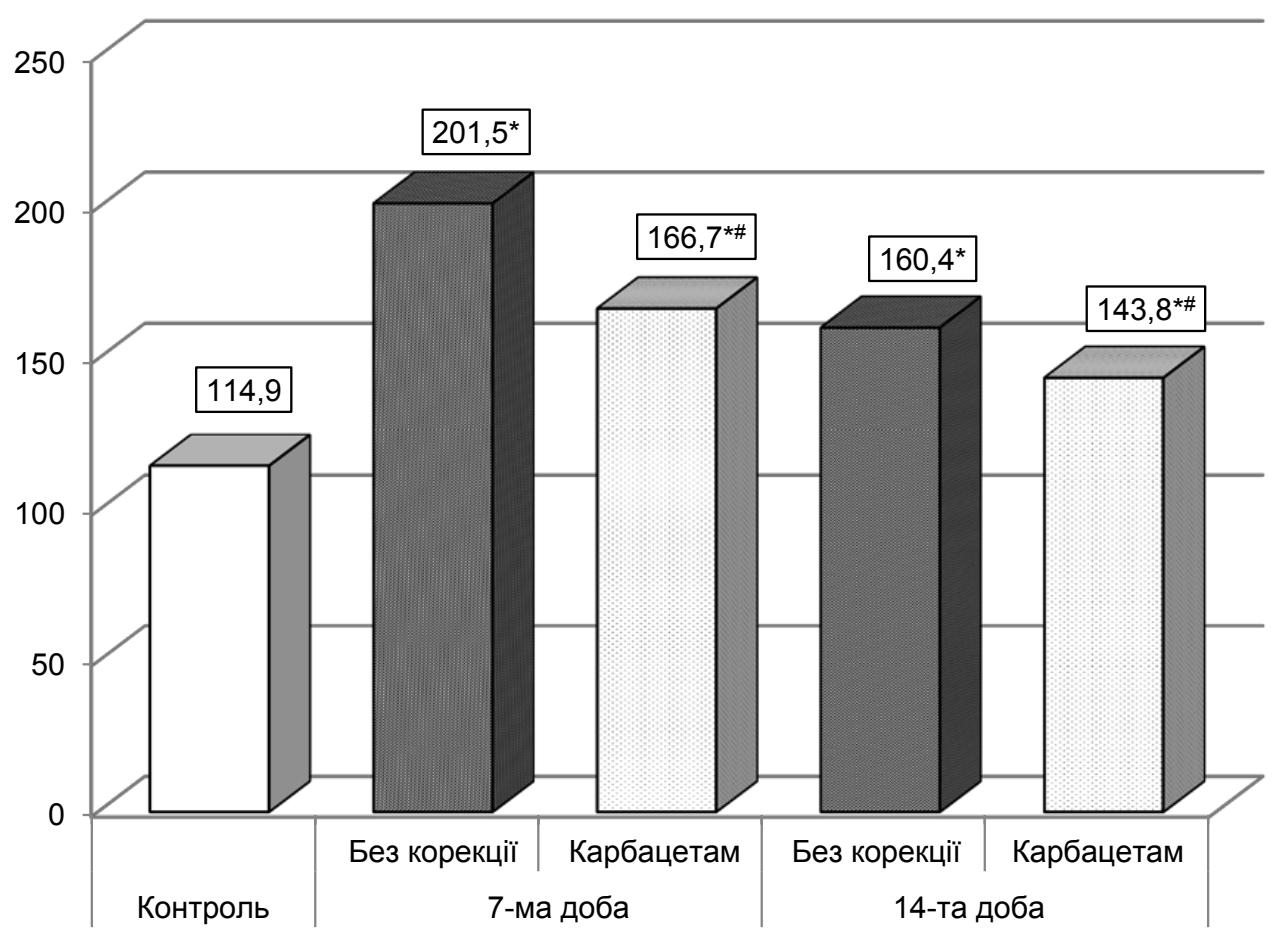

Рис. 2. Вплив карбацетаму на активність аспартатамінотранссрерази в сироватці крові $\left(О д \cdot{ }^{-1}\right)$ після гострої крововтрати, ускладненої ішемією-реперфузією кінцівки.

зменшення проявів ішемії-реперфузії кінцівки за умов гострої крововтрати.

ВИСНОВКИ. 1. Заумов моделювання гострої крововтрати, ускладненої двогодинною ішемією кінцівки, в реперфузійний період відмічають посилення цитолітичного синдрому, що проявляється зростанням у сироватці крові активності аланін- і аспартатамінотрансфераз із максимумом через 1 добу, яка не стихає до 14-ї доби і суттєво перевищує показники дослідних груп, в яких моделювали лише гостру крововтрату чи ішемію-реперфузію кінцівки.

2. Застосування карбацетаму в дозі 5 мг/кг внутрішньочеревно щоденно протягом 7-14 діб

\section{СПИСОК ЛІТЕРАТУРИ}

1. Point of injury tourniquet application during Operation Protective Edge-What do we learn? / A. Shlaifer, A. Yitzhak, E. N. Baruch [et al.] // J. Trauma Acute Care Surg. - 2017. - 83, Issue 2. - P. 278-283.

2. Volotovska N. V. Changes in the glutathione syss tem's activity of internal organs in the first hours of experimental limb ischemia-reperfusion syndrome, combined with blood loss and mechanical injury / N. V. Volotovska, T. C. Nhokwara, I. V. Zhulkevych // Здобутки клінічної і експериментальної медицини. 2019. - № 1. - C. 23-27. URL : https://doi. org/10.11603/1811-2471.2019.v0.i1.10043. у щурів із гострою крововтратою, ускладненою ішемією-реперфузією кінцівки, порівняно 3 тваринами без корекції, зумовлює статистично значуще зниження активності в сироватці крові аланін- і аспартатамінотрансфераз, що вказує на перспективність використання препарату в комплексній корекції виявлених порушень та доводить вагому роль процесів цитолізу в патогенезі досліджуваної патології.

Перспективи подальших досліджень. У перспективі доцільно розширити спектр дослідження активності карбацетаму за умов гострої крововтрати, ускладненої ішемією-реперфузією кінцівки.

3. Максимів Р. В. Динаміка балансу антиоксидантно-прооксидантних механізмів у внутрішніх органах під впливом артеріального джгута і реперфузії кінцівки / Р. В. Максимів, А. А. Гудима, В.М. Сидоренко // Шпитальна хірургія. Журн. імені Л. Я. Ковальчука. 2017. - № 1 (77). - С. 37-44.

4. Шацький В. В. Динаміка антиоксидантно-прооксидантного балансу кіркового і мозкового шарів нирки після гострої крововтрати, ускладненої ішемієюреперфузією кінцівки, та його корекція карбацетамом / В.В.Шацький, А. А. Гудима, Л. Я. Федонюк // Здобутки клініч. і експерим. медицини. -2019. - № 4. - С. 144-153. 
5. Кузьмінський І. В. Вплив ішемічно-реперсрузійного синдрому на активацію системи перекисного окиснення ліпідів у тканині печінки / І. В. Кузьмінський // Клініч. та експерим. патологія. - 2018. № 4 (66). - С. 53-59.

6. Цимбалюк Г. Ю. Стан системи пероксидного окиснення ліпідів у тканині нирки на фоні травми органів черевної порожнини та реперфузії кінцівок / Г. Ю. Цимбалюк // Екстрена медицина: від науки до практики. - 2018. - № 3 (29). - С. 23-32.

7. Козак Д. В. Вплив політравми на динаміку пізнього апоптозу тканинних лімсроцитів / Д. В. Козак, А. А. Гудима // Клініч. хірургія. - 2013. - № 9 (848). C. $70-72$.

8. Гудима А. А. Антиоксидантно-прооксидантний та цитокіновий баланс у пізній період комбінованої травми в експерименті / А. А. Гудима, Т. В. Кащак, К. В. Шепітько // Світ медицини та біології. - 2019. № 1 (67). - C. 42-47.

\section{REFERENCES}

1. Shlaifer, A., Yitzhak, A., Baruch, E.N., Shina, A., Satanovsky, A., Shovali, A., Almog, O., \& Glassberg, E. (2017). Point of injury tourniquet application during Operation Protective Edge-What do we learn? J. Trauma Acute Care Surg., 83, 2, 278-283.

2. Volotovska, N.V., Nhokwara, T.C., \& Zhulkevych, I.V. (2019). Changes in the glutathione systems activity of internal organs in the first hours of experimental limb ischemia-reperfusion syndrome, combined with blood loss and mechanical injury. Zdobutky klinichnoi i eksperymentalnoi medytsyny - Achievements of Clinical and Experimental Medicine, (1), 23-27. Retrieved from: https:// doi.org/10.11603/1811-2471.2019.v0.i1.10043

3. Maksymiv, R.V., Hudyma, A.A., \& Sydorenko, V.M. (2017). Dynamika balansu antyoksydantno-prooksydantnykh mekhanizmiv u vnutrishnikh orhanakh pid vplyvom arterialnoho dzhhuta i reperfuzii kintsivky [Dynamics of balance of antioxidant-prooxidant mechanisms in internal organs under the influence of arterial tourniquet and limb reperfusion]. Shpytalna khirurhiia. Zhurnal imeni L. Ya. Kovalchuka - Hospital Surgery. Journal named after L. Ya. Kovalchuk, 1, 37-44 [in Ukrainian].

4. Shatsky, V.V., Hudyma, A.A., \& Fedoniuk, L.Ya. (2019). Dynamika antyoksydantno-prooksydantnoho balansu kirkovoho i mozkovoho shariv nyrky pislia hostroi krovovtraty, uskladnenoi ishemiieiu-reperfuziieiu kintsivky, ta yoho korektsiia karbatsetamom [Dynamics of antioxidant-prooxidant balance of renal cort ex and medulla after acute blood loss complicated by ischemia-reperfusion of the extremity, and its correction with carbacetam]. Zdobutky klinichnoi i eksperymentalnoi medytsyny Achievements of Clinical and Experimental Medicine, 4, 144-153 [in Ukrainian].

5. Kuzminskyi, I.V. (2018). Vplyv ishemichno-reperfuziinoho syndromu na aktyvatsiiu systemy perekysnoho okysnennia lipidiv u tkanyni pechinky [The effect of ischemic-reperfusion syndrome on the activation of the lipid peroxidation system in liver tissue]. Klinichna ta
9. Козак Д. В. Динаміка показників цитолізу в умовах політравми / Д. В. Козак // Шпитальна хірургія. -2012 . - № 2 (58). - С. 50-52.

10. Козак Д. В. Структурні зміни деяких внутрішніх органів тварин із модельованою політравмою за умов корекції карбацетамом / Д. В. Козак, К. С. Волков // Наук. вісн. УжНУ. Серія: "Медицина". - 2014. Вип. 2 (50). - С. 3-6.

11. Максимів Р. Динаміка ліпідної пероксидації в печінці під впливом артеріального джгута і реперфузії кінцівки / Р. Максимів, І. Горбань, І. Стрельбицька // XXII Міжнародний медичний конгрес студентів та молодих вчених : матеріали (23-25 квіт. 2018 р.). Тернопіль : ТДМУ, 2018. - С. 266.

12. Кузьмінський І. В. Вплив ішемічно-реперфрузійного синдрому кінцівок на відхилення показників цитолітичного синдрому / І. В. Кузьмінський // Здобутки клініч. і експерим. медицини. - 2018. - № 3 (35). С. 176-181. eksperymentalna patolohiia - Clinical and Experimental Pathology, 4 (66), 53-59 [in Ukrainian].

6. Tsymbalyuk, H.Yu. (2018). Stan systemy peroksydnoho okysnennia lipidiv u tkanyni nyrky na foni travmy orhaniv cherevnoi porozhnyny ta reperfuzii kintsivok [The state of the lipid peroxidation system in the kidney tissue against the background of trauma to the abdominal organs and reperfusion of the extremities]. Ekstrena medytsyna: vid nauky do praktyky -Emergency Medicine: From Science to Practice, 3 (29), 23-32 [in Ukrainian].

7. Kozak, D.V., \& Hudyma, A.A. (2013). Vplyv politravmy na dynamiku piznoho apoptozu tkanynnykh limfotsytiv [Influence of polytrauma on the dynamics of late apoptosis of tissue lymphocytes]. Klinichna khirurhiia - Clinical Surgery, 9 (848), 70-72 [in Ukrainian].

8. Hudyma, A.A., Kashchak, T.V., \& Shepitko, K.V. (2019). Antyoksydantno-prooksydantnyi ta tsytokinovyi balans u piznii period kombinovanoi travmy v eksperymenti [Antioxidant-prooxidant and cytokine balance in the late period of combined trauma in the experiment]. Svit medytsyny ta biolohii - World of Medicine and Biology, 1 (67), 42-47 [in Ukrasinian].

9. Kozak, D.V. (2012). Dynamika pokaznykiv tsytolizu $v$ umovakh politravmy [Dynamics of cytolysis in conditions of polytrauma]. Shpytalna khirurhiia-Hospital Surgery, 2 (58), 50-52 [in Ukrainian].

10. Kozak, D.V., \& Volkov, K.S. (2014). Strukturni zminy deiakykh vnutrishnikh orhaniv tvaryn iz modelovanoiu politravmoiu za umov korektsii karbatsetamom [Structural changes of of some internal organs by animals with simulated polytrauma and correction with carbacetam]. Naukovyy visnyk UzhNU Seriia: "Medytsyna" Scientific Bulletin of UzhNU Series: "Medicine", 2 (50), 3-6 [in Ukrainian].

11. Maksymiv, R., Horban, I., \& Strelbytska, I. (2018). Dynamika lipidnoi peroksydatsii v pechintsi pid vplyvom arterialnoho dzhhuta i reperfuzii kintsivky [Dynamics of lipid peroxidation in the liver under the influence of arterial 
tourniquet and limb reperfusion]. XXII Mizhnarodnyi medychnyi konhres studentiv ta molodykh vchenykh: materialy (23-25 kvit. 2018 r.) - XXII International Medical Congress of Students and Young Scientists: Materials (April 23-25, 2018). Ternopil: Ukrmedknyha [in Ukrainian].

12. Kuzminskyi, I.V. (2018). Vplyv ishemichno-reperfuziinoho syndromu kintsivok na vidkhylennia pokaznykiv tsytolitychnoho syndromu [Influence of ischemicreperfusion syndrome of extremities for cytolytic syndrome]. Zdobutky klinichnoi i eksperymentalnoi medytsyny - Achievements of Clinical and Experimental Medicine, 3 (35), 176-181 [in Ukrainian].

И. И. Горбань, А. А. Гудыма, Р. В. Максымив ТЕРНОПОЛЬСКИЙ НАЦИОНАЛЬНЫЙ МЕДИЦИНСКИЙ УНИВЕРСИТЕТ ИМЕНИ И. Я. ГОРБАЧЕВСКОГО МОЗ УКРАИНЫ

\section{ДИНАМИКА ПОКАЗАТЕЛЕЙ ЦИТОЛИЗА В УСЛОВИЯХ ОСТРОЙ КРОВОПОТЕРИ, ОСЛОЖНЕННОЙ ИШЕМИЕЙ-РЕПЕРФУЗИЕЙ КОНЕЧНОСТИ, И ИХ КОРРЕКЦИЯ КАРБАЦЕТАМОМ}

\section{Резюме}

Вступление. Основным средством спасения раненых на поле боя в условиях массивной кровопотери из конечностей является применение кровоостанавливающего жгута. Известно, что полное обескровливание конечности в течение 2 ч в реперфузионный период сопровождается активацией процессов липидной пероксидации, которая усиливается при острой кровопотере, сопровождается деградацией клеточных мембран и вызывает развитие синдрома цитолиза.

Цель исследования - выяснить динамику показателей цитолиза в условиях острой кровопотери, осложненной ишемией-реперфузией конечности, и эфрфективность их коррекции карбацетамом.

Методы исследования. В экспериментах на нелинейных белых крысах-самцах под тиопентал-натриевым наркозом моделировали двухчасовую ишемию конечности с последующей реперфузией, острую кровопотерю (20 \% от объема циркулирующей крови) и сочетали эти повреждения. В отдельной опытной группе в условиях острой кровопотери и ишемии-реперфузии конечности крысам с коррекционной целью внутрибрюшно вводили карбацетам в дозе 5 мг/кг массы животного. В контрольной группе крыс вводили в наркоз. Через 1 и 2 ч, а также через 1, 7 и 14 суток под тиопентал-натриевым наркозом подопытных животных выводили из эксперимента методом тотального кровопускания из сердца. В сыворотке крови определяли содержание маркеров цитолиза: активность аланин- и аспартатаминотрансфрераз (АлАТ, АсАT).

Результаты и обсуждение. Моделирование ишемии-реперфузии конечности сопровождалось выраженным цитолитическим синдромом, что, по сравнению с контролем, проявлялось существенным ростом активности в сыворотке крови АлАТ и АсАТ через 3 ч и 1 сутки наблюдения. Начиная с 7 суток, показатели нормализовались. Моделирование острой кровопотери углубляло активность процессов цитолиза. Исследуемые показатели были больше уровня контроля во все сроки наблюдения с максимумом через 1 сутки эксперимента и существенно превышали показатели опытной группы, в которой моделировали только ишемию-реперфузию конечности. В условиях острой кровопотери, осложненной ишемией-реперфузией конечности, нарушения были более значительными. Исследуемые показатели существенно превышали во все сроки наблюдения контрольную и другие опытные группы: активность АлАТ - через 1-14 суток наблюдения, АсАТ - через 2 ч - 7 суток. Применение с целью коррекции карбацетама у крыс с острой кровопотерей, осложненной ишемией-реперфузией конечности, показало, что через 7-14 суток его использования активность АлАТ и АсАТ в сыворотке крови, по сравнению с животными без коррекции, существенно снижалась, однако не достигала уровня контроля.

Вывод. Полученные результаты свидетельствуют о весомой роли процессов цитолиза в патогенезе острой кровопотери, осложненной ишемией-реперфузией конечности, а также о перспективности использования карбацетама как комплексного средства для уменьшения проявлений ишемии-реперфузии конечности в условиях острой кровопотери.

КЛЮЧЕВЫЕ СЛОВА: острая кровопотеря; ишемия-реперфузия конечности; цитолитический синдром; карбацетам. 


\section{THE DYNAMICS OF CYTOLYSIS MARKERS UNDER CONDITIONS OF ACUTE BLOOD LOSS COMPLICATED BY LIMB ISCHEMIA-REPERFUSION AND THEIR CORRECTION BY CARBACETAM}

\section{Summary}

Introduction. The main means of saving the wounded on the battlefield in conditions of massive blood loss from the limbs is the use of a hemostatic tourniquet. It is known that complete bleeding of the extremity for 2 hours during the reperfusion period is accompanied by activation of lipid peroxidation processes, which increases with acute blood loss, is accompanied by degradation of cell membranes and causes the development of cytolysis syndrome.

The aim of the study - to determine the dynamics of cytolysis markers in the presence of acute blood loss complicated by limb ischemia-reperfusion and the efficacy of their correction by carbacetam.

Research Methods. In experiments on nonlinear white male rats under thiopental sodium anesthesia, two-hour limb ischemia was simulated followed by reperfusion, acute blood loss (20\% of the circulating blood volume), and these injuries were combined. In a separate study group in conditions of acute blood loss and limb ischemiareperfusion, rats were injected intraperitoneally with a dose of $5 \mathrm{mg} / \mathrm{kg}$ of animal weight for rats with a corrective purpose. In the control group, rats were anesthetized. After 1 and 2 hours, and also after 1, 7 and 14 days under thiopental sodium anesthesia, experimental animals were removed from the experiment by the method of total bloodletting from the heart. The content of cytolysis markers in the blood serum was determined: the activity of alanine and aspartate aminotransferases (AIAT, ASAT).

Results and Discussion. Modeling of limb ischemia-reperfusion was accompanied by a pronounced cytolytic syndrome, which, in comparison with the control, was manifested by a significant increase in serum activity of AlAT and AsAT after 3 hours and 1 day of observation. Starting from 7 days, the indicators returned to normal. Modeling of acute blood loss deepened the activity of cytolysis processes. The studied parameters were greater than the control level at all observation periods with a maximum after 1 day of the experiment and significantly exceeded the parameters of the research group, in which only limb ischemia-reperfusion was modeled. In conditions of acute blood loss complicated by ischemia-reperfusion of the limb, the disorders were more significant. The studied parameters significantly exceeded the control and other research groups during all observation periods: AlAT activity - after 1-14 days of observation, AsAT - after 2 hours - 7 days. The use for the correction of carbacetam in rats with acute blood loss complicated by limb ischemia-reperfusion showed that after 7-14 days of its use, the activity of AIAT and AsAT in blood serum decreased significantly compared to animals without correction, but did not reach the control level.

Conclusions. The results obtained indicate a significant role of cytolysis processes in the pathogenesis of acute blood loss complicated by limb ischemia-reperfusion, as well as the prospect of using carbacetam as a comprehensive tool to reduce the manifestations of limb ischemia-reperfusion in acute blood loss.

KEY WORDS: acute blood loss; limb ischemia-reperfusion; cytolytic syndrome; carbacetam.

Отримано 08.05.20

Адреса для листування: А. А. Гудима, Тернопільський національний медичний університет імені І. Я. Горбачевського мОз України, майдан Волі, 1, Тернопіль, 46001, Україна, e-mail: arsgudyma@gmail.com. 